\title{
Hubungan Antara Kecerdasan Emosional dan Dark Triad of Personality pada Narapidana LPKA Kelas II Tomohon
}

\author{
(Relationship between emotional intelligence and dark triad of personality on \\ Tomohon LPKA 2nd grade's convict) \\ Yerico Cerio Memah* dan Krismi Diah Ambarwati \\ Universitas Kristen Satya Wacana, Salatiga, Indonesia \\ *yericomemah@gmail.com
}

\begin{abstract}
Abstrak
Penelitian ini bertujuan mengetahui hubungan antara kecerdasan emosional dengan dimensidimensi dark triad of personality yakni machiavellianism, narcissism, dan psychopathy pada narapidana LPKA Kelas II Tomohon. Terdapat 2 alat ukur yang digunakan dalam penelitian ini. Pertama, Schutte Self-report Emotional Intelligence (SSEI), yang dikembangkan oleh Cooper, Dornheim, Golden, Hall, Haggerty, Malouff dan Schutte (1998) dari Salovey dan Mayer (1990), dan yang kedua adalah Short Dark Triad (SD3) dari Jones dan Paulhus (2014). Teknik pengambilan sampel yang digunakan dalam penelitian ini adalah teknik sampling jenuh yaitu dengan mengambil seluruh populasi narapidana di LPKA Kelas II Tomohon untuk dijadikan sampel (Azwar, 2012). Keseluruhan sampel tersebut adalah sebanyak 16 narapidana. Berdasarkan hasil analisis data, tidak terdapat hubungan negatif yang signifikan antara kecerdasan emosional dengan kepribadian dark triad. Artinya ketika terjadi peningkatan atau penurunan kecerdasan emosional, tidak ada kaitannya dengan peningkatan atau penurunan kepribadian dark triad. Oleh karena itu hipotesis dalam penelitian ini tidak diterima.

Kata kunci: Kecerdasan Emosional, Dark Triad of Personality, Narapidana
\end{abstract}

\begin{abstract}
This study aims to determine the relationship between emotional intelligence and dark triad of personality dimensions, namely machiavellianism, narcissism, and psychopathy on Tomohon LPKA $2^{\text {nd }}$ grade's convict. There are two measuring instruments used in this research. First, Schutte Self-report Emotional Intelligence (SSEI), which was developed by Cooper, Dornheim, Golden, Hall, Haggerty, Malouff and Schutte (1998) from Salovey and Mayer (1990) and the second one is Short Dark Triad (SD3) from Jones and Paulhus (2014). The sampling technique used in this study was a saturated sampling technique, namely by taking the entire population of convicts in Tomohon LPKA $2^{\text {nd }}$ grade's to be the sample (Azwar, 2012). The total sample was 16 convicts. Based on the results of data analysis, there is no significant negative relationship between emotional intelligence and dark triad of personality. This means that when there is an increase or decrease in emotional intelligence, it has nothing to do with an increase or decrease in the dark triad of personality. Therefore, the hypothesis in this study is not accepted.
\end{abstract}

Keywords: Emotional Intelligence, Dark Triad of Personality, Convict

\section{PENDAHULUAN}

Data terbaru dari Badan Pusat Statistik (BPS) (2019), pada tahun 2017 angka kriminalitas di Indonesia mencapai 336.625 kasus (Kusnandar, 2019). BPS kemudian membuat pengelompokan 10 daerah dengan tindak kejahatan yang sangat tinggi di Indonesia. Provinsi Sulawesi Utara merupakan salah satunya, yaitu dengan tindak kriminalitas sebesar 10.247 kasus dan berada pada urutan ke 8 di atas Sulawesi Tengah dan Jawa Tengah. Melihat 
dari faktor risiko kejahatan yang ada (crime rate), Sulawesi Utara berada pada urutan pertama yaitu sebanyak 416 kasus kejahatan disusul Papua Barat 380 kasus (Jayani, 2019).

Tindakan kejahatan yang terjadi tidak hanya dilakukan oleh orang dewasa, melainkan juga anak. Dilansir dari Institute for Criminal Justice Reform (ICJR) jumlah anak yang terdaftar dalam Unit Pelayanan Terpadu yang dikelola oleh Direktorat Jenderal Pemasyarakatan (Ditjen PAS) pada tahun 2016 lalu, mengalami peningkatan yang cukup signifikan. Tercatat hingga bulan Juni 2017 ada sekitar 910 tahanan yang dikelola Ditjen PAS, terdapat 895 tahanan laki-laki dan 15 lainnya adalah perempuan (Zuraya, 2017). Jumlah tahanan ini belum termasuk tahanan anak yang dikelola oleh Kepolisian Republik Indonesia (Zuraya, 2017). Data dari Komisi Perlindungan Anak Indonesia (KPAI) tahun 2019, setiap tahun terjadi peningkatan kasus kriminalitas dari anak, sejak 2011 sampai dengan 2018 tercatat 11.116 kasus kriminalitas dengan kenakalan remaja lainnya ialah tawuran antar kampung (tarkam) dan minuman keras (miras).

Diananda (2018), berpendapat bahwa secara psikologis, kenakalan remaja wujud daripada konflik yang tidak diselesaikan dengan baik pada masa kanak-kanak, sehingga fase remaja gagal dalam menjalani proses perkembangan jiwanya. Selain berdampak pada tahapan perkembangan selanjutnya, kegagalan masa transisi juga cenderung memengaruhi sosio-emosional dari remaja itu sendiri, yang kemudian akan berpengaruh terhadap seluruh tindakan yang akan diambil. Dalam masa peralihan, remaja dihadapkan pada masalah-masalah penguasaan diri atau kontrol diri (Diananda, 2018). Jika gagal maka akan memicu perilaku yang menyimpang dari norma sosial masyarakat yang kemudian dimanifestasikan dengan perilaku kenakalan remaja. Hal ini sama seperti yang dikemukakan oleh Loeber dan Schmaling (1985), bahwa kemungkinan terjadinya perubahan perilaku menyimpang menjadi perilaku mengganggu diakibatkan adanya disfungsi perkembangan yang kumulatif yaitu terjadinya penumpukan masalah yang berlangsung sejak tahap perkembangan sebelumnya dari individu tersebut. Didukung oleh pendapat Dishion, Dodge dan Lansford (2006) yang menyatakan bahwa kenakalan remaja sebenarnya adalah ketidakmampuan melakukan tugas perkembangan dengan cara yang adaptif sehingga cenderung melakukan perilaku yang mal adaptif. Dalam masa perkembangannya, remaja di tuntut untuk mampu mengenal diri dengan baik agar dapat mengatasi faktor-faktor dari pengaruh lingkungan (Bahiyah, Dewi, Idulfilastri, \& Marat, 2019). Kewaspadaan dalam berpikir ke depan dan persiapan diri menjadi salah satu faktor utama bekal dari remaja untuk menghadapi risiko lingkungan tersebut (Bahiyah, dkk., 2019).

Kenakalan remaja yang di dalamnya terdapat kontrol diri yang tidak baik dapat menjadi jembatan untuk dark triad of personality muncul dalam diri individu, selaras halnya dengan temuan penelitian Almeida, Almosaed, Bashatah, Moghrabi, Morgan, dan Wright (2016), yang mendapatkan bahwa kenakalan remaja cenderung akan membuat kontrol diri menjadi rendah yang akan memicu perilaku berbahaya. Dark triad of personality merupakan istilah subklinis untuk kepribadian gelap atau 3 (tiga) konstelasi/susunan sosial ciri-ciri kepribadian permusuhan dari setiap individu, yang terdiri dari 3 (tiga) dimensi yaitu subclinical machiavellianism, subclinical narcissism, dan subclinical psychopathy (Paulhus \& Williams, 2002). Jones dan Paulhus (2011), mengasosiasikan bahwa dark triad of personality merupakan serangkaian tipe kepribadian jahat yang ada pada individu dengan 3 konstruksi dimensi di dalamnya seperti yang diungkapkan Paulhus dan Williams (2002). Secara menyeluruh, dark triad of personality ini mencakup kepribadian individu yang cenderung akan berpura-pura lemah pada suatu kondisi untuk menarik perhatian agar lingkungan sekitar memperhatikannya, tidak berprinsip, cenderung mendominasi, memegahkan diri sendiri, mencari sensasi, kurangnya rasa empati dan memiliki kecemasan yang rendah (Shepperd \& Socherman, 1997; Jones \& Paulhus, 2014; Hare \& Neumann, 2008; Jones \& Paulhus, 2009). Dari 
ketiga dimensi yang ada pada dark triad of personality, dipastikan ada salah satu dimensi yang lebih dominan di dalam diri individu walaupun ketiganya saling tumpang tindih terhadap satu dengan lainnya (Furnham, Richards, \& Paulhus, 2013). Individu dengan dark triad of personality yang dominan cenderung akan menjadi kejam dan berusaha untuk menggapai apa yang mereka inginkan lewat jalan pintas dan dengan cara apa pun (Furnham, dkk., 2013).

Dimensi pertama dari dark triad of personality ialah machiavellianism, yang merupakan karakteristik individu dengan kecenderungan berperilaku dingin dan manipulatif di kehidupan sehari-hari. Individu akan cenderung memiliki relasi interpersonal yang manipulatif dan penuh perhitungan. Menurut Fehr, Samsom, dan Paulhus (1992), konsep machiavellianism membuat individu memiliki pandangan terhadap dunia menjadi sinis, kurangnya moralitas, dan penuh manipulatif. Dimensi kedua ialah narcissism yang mengacu pada Diagnostic and Statistical Manual of Mental Disorders (DSM). Aspek yang dipertahankan dari sindrom klinisnya adalah memegahkan diri sendiri, merasa berhak, dominasi, dan superioritas. Menitikberatkan pada perilaku narsistik dengan ditandai oleh manipulasi, tidak berperasaan, kurangnya rasa empati, hampir sama dengan konsep machiavellianism dan psikopati (Paulhus \& Williams, 2002). Secara intrinsik, narcissism didefinisikan sebagai bentrokan antara identitas dan rasa tidak aman yang mendasarinya (Bende, Berghuis, Krueger, Morey, Skodol, \& Verheul, 2011; Ansell, Cain, Levy, Pimentel, Pincus, \& Wright, 2009). Dimensi yang ketiga ialah psychopathy dengan karakter pusatnya yakni impulsif tinggi dan pencari sensasi disertai dengan rasa empati dan kecemasan yang rendah. Elemen kunci dari psikopati adalah defisit dalam perasaan (yaitu, tidak berperasaan) dan kontrol diri (yaitu, impulsif) (Cleckley, 1976; Hare, 1970). Manipulasi perasaan ini akan menghasilkan sebuah keberanian dalam diri inividu dan mendorongnya untuk memanifestasikan perilaku kriminal yang tanpa henti (Hare \& Neumann, 2008).
Penelitian mengenai dark triad of personality ini merupakan suatu bagian yang penting karena inilah yang menjadi salah satu dari pendorong remaja melakukan kriminalitas. Hal ini berangkat dari fase kegagalan masa transisi yang berujung terhadap terjadinya krisis identitas. Krisis identitas merupakan suatu manifestasi dari kekaburan identitas yang membuat remaja mengalami kebimbangan dalam mengontrol dirinya. Serupa dengan Andrianto (2019) yang mengungkapkan bahwa kekaburan identitas pada remaja menyebabkan krisis identitas terjadi, sehingga kontrol menjadi semakin lemah dan membawa akibat bagi remaja untuk menjadi brutal atau tidak terkontrol. Keadaan yang tidak dapat terkendali dari remaja merupakan perwujudan dari kepribadian yang beragam dan inilah yang kemudian menjadi pemicu dark triad of personality muncul. Dark triad of personality ini akan menampilkan suatu strategi kehidupan bagi individu yang mengabaikan aturan sosial, mempunyai pikiran jangka pendek dan perilaku yang mencari keuntungan (Jonason \& Webster, 2012). Menurut Febiyanti dan Wijaya (2017), perilaku-perilaku menyimpang yang mengarah pada kenakalan remaja merupakan suatu hasil dari kecerdasan emosional dengan tingkatan rendah. Nikolaou, Tsaousis, dan Valoka (2004), berpendapat bahwa kecerdasan emosional akan sangat berpotensi pada pembentukan tindakan dan kepribadian individu. Hal ini menjadi pertanda bahwa kecerdasan emosional merupakan salah satu faktor yang memengaruhi dark triad of personality.

Baron (dalam Goleman, 2000) mengidentifikasi kecerdasan emosional sebagai serangkaian kemampuan pribadi, emosi dan sosial yang memengaruhi kemampuan seseorang untuk berhasil dalam mengatasi tuntutan dan tekanan lingkungan. Mayer dan Salovey (1989) mengungkapkan bahwa kecerdasan emosional merupakan suatu bagian dari kecerdasan sosial yang melibatkan kemampuan untuk memantau perasaan dan emosi seseorang dengan orang lain. Emosi pada dasarnya merupakan dorongan untuk bertindak. 
Tindakan yang dihasilkan tergantung dari stimulus yang diterima dari setiap individu dan emosi tidak selalu mengeluarkan sesuatu yang negatif. Menurut Goleman (1999), emosi merujuk pada suatu perasaan dan pikiran yang khas, yakni suatu keadaan biologis dan psikologis serta serangkaian kecenderungan untuk bertindak. Kecerdasan emosional saat ini dipahami secara luas sebagai kemampuan untuk memahami, mengatur dan mengelola emosi diri sendiri dan orang lain (Caruso, Mayer \& Salovey, 2004).

Mayer dan Salovey (1997); Caruso, Mayer dan Salovey, (2002) mengungkapkan bahwa ada 4 (empat) aspek kecerdasan emosional yang disebut sebagai four-branch model of emotional intelligence, yaitu merasakan emosi yang didefinisikan sebagai kemampuan memahami sekaligus mengidentifikasi emosi dari diri sendiri dan orang lain, menggunakan emosi sebagai cara memfokuskan perhatian dan berpikir lebih rasional, memahami emosi sebagai cerminan dari kapasitas emosi dan mengelola emosi yang merupakan kemampuan untuk mengatur suasana hati serta emosi diri sendiri dan orang lain. Baron (1997), telah menempatkan kecerdasan emosional dalam konteks teori kepribadian. Ia mendefinisikan kecerdasan emosional sebagai konsep payung dari kemampuan non-kognitif, kompetensi, dan keterampilan yang membantu seseorang untuk menjadi lebih efisien dalam mengatasi tuntutan dan tekanan lingkungan. Menurutnya, kecerdasan emosional menjadi hal yang sangat penting dalam mengembangkan keterampilan di lingkungan sekitar dari individu. Remaja tidak akan berhasil mengatasi tuntutan dan tekanan yang didapatkan dari lingkungannya jika ia mengalami kegagalan pada proses perkembangannya. Kecerdasan emosional yang baik cenderung akan membuat remaja berada konteks kehidupan yang normal, tetapi jika kecerdasan emosional itu terganggu maka cenderung akan memicu perilaku yang beragam mengarah pada tindakan yang tidak terkontrol atau yang disebut sebagai manifestasi dari dark triad of personality.
Davis dan Stone (2003), berpendapat bahwa keberhasilan individu dalam memanipulasi sesuatu, dapat diasumsikan sebagai tipe machiavellianism dengan kecerdasan superior khususnya yang berkaitan dengan memahami orang lain dalam situasi sosial. Tetapi hal itu dibantah oleh Jones dan Paulhus (2009), yang menyatakan bahwa keberhasilan manipulasi tersebut bukan berasal dari kecerdasan superiornya melainkan dari regulasi dorongan yang superior. Kecerdasan emosional juga memiliki kaitannya dengan narcissism dalam hal sifat dan perilaku yang diinginkan dan adaptif secara sosial (Holman, Niven \& Totterdell, 2012). Narcissism dapat memanipulasi dan mengeksploitasi orang lain, yang menjadi penanda bahwa kompetensi emosionalnya berada pada tingkatan rendah (Furtner, Nagler, Rauthmann, \& Reiter, 2014). Sependapat dengan Bushman, Corneille, Konrath, dan Luminet (2014), yang mengemukakan bahwa eksploitasi tersebut adalah sebuah keaslian dari individu tersebut, dan dapat dikatakan bahwa narcissism paling dekat hubungannya dengan manipulasi dan secara positif berkaitan dengan pengenalan ketrampilan emosi. Selanjutnya, dalam hal kecerdasan emosional dan tipe psychopathy, Ali, Amorim, dan ChamorroPremuzic (2009); Ashton, Bogaert, Pozzebon, dan Visser (2010), menjelaskan bahwa orang dengan sifat ini cenderung akan mengalami defisit di dalam kemampuannya terutama dalam mendeteksi dan memahami emosi orang lain serta kurang mampu mengatur suasana hatinya. Sebagai tambahan, Hare (2003); Gilbert dan Morrison (2001), mengemukakan bahwa tipe psychopathy akan memiliki penurunan dalam emosi moral sehingga akan membuat suatu ketidakpedulian situasi yang menghasilkan rasa malu atau kurangnya kontrol impuls.

Penelitian Austin, Black, Farrelly, dan Moore (2007) menganalisis faktor skala manipulasi emosional dengan hasil memperlihatkan adanya korelasi positif antara manipulasi emosional dengan machiavellianism. Lebih lanjut dijelaskan, bahwa temuan ini bisa jadi hanya mendukung item 
manipulasi emosional tetapi tidak begitu berhasil dalam penggunaan strateginya atau dengan kata lain emosi yang ditampilkan merupakan kiat-kiat yang hanya diturunkan secara kognitif saja. Dalam hal narcissism, Further, Rauthmann dan Sachse (2011), menemukan bahwa pengontrolan diri dan pemantauan diri berhubungan secara positif dengan narcissism. Kaitan ini pada dasarnya merupakan dorongan manifestasi dari domain yang berbeda-beda seperti, intelektual kerja, daya tarik fisik, dominasi bahkan orientasi komunal. Selaras halnya yang ditemukan oleh Petrides, Schermer, Vernon dan Veselka (2011) yang dalam penelitiannya melihat perpaduan dari analisis perilaku genetik, fenotipik dan lingkungan antara kecerdasan emosional dan dark triad of personality dengan hasil yang menunjukkan bahwa kecerdasan emosional (ketegasan, emosi, manajemen, harga diri, kesadaran dan faktor-faktor sosiabilitas) memiliki korelasi kuat dengan narcissism, sedangkan untuk machiavellianism dan psychopathy berhubungan secara positif dengan kecerdasan emosional melalui faktor-faktor emosi, kontrol diri, keramahan dan kesejahteraan secara emosional. Kemudian untuk psychopathy, Ali, Amorim dan Chamorro-Premuzic, (2009); Bereczkei dan Szabo, (2017), menemukan bahwa kecerdasan emosional berhubungan secara negatif dengan psychopathy primer melalui perhatian akan perasaan diri sendiri. Hal ini mengingatkan bahwa individu dengan skor tinggi dalam hal ini subtipe psychopathy menunjukkan kecenderungan penurunan pada perhatian akan emosi mereka sendiri. Glass, Malterer dan Newman (2008), mengemukakan bahwa kesulitan dalam memproses ekspresi dari emosi menjadi faktor kunci dalam pengembangan kecenderungan psikopati.

Melihat dari variasi studi penelitian-penelitian yang sangat beragam dari hubungan antara kecerdasan emosional dan dark triad of personality, memberikan arti secara jelas bahwa hasil uji korelasi antara 2 (dua) variabel tersebut dapat dikatakan belum konklusif, oleh karena itu penelitian ini bertujuan untuk menguji kembali korelasi antara kedua variabel tersebut. Penelitian ini akan berfokus kepada narapidana remaja karena dalam hal ini peneliti menduga bahwa ketika terjadi peningkatan ataupun penurunan kecerdasan emosional pada narapidana remaja, maka hal tersebut pula akan berhubungan dengan peningkatan maupun penurunan dark triad of personality. Ini sangat penting untuk dipelajari lebih dalam mengingat hasil keterkaitan antar kedua variabel berbeda-beda. Selain itu juga, peneliti berharap bahwa penelitian ini dapat menjadi acuan dan tolak ukur untuk penelitian selanjutnya mengenai korelasi antara kecerdasan emosional dan dark triad of personality.

Adapun beberapa hipotesis yang diajukan peneliti dari penelitian ini, yakni terdapat hubungan negatif antara kecerdasan emosional dengan machiavellianism pada narapidana remaja di LPKA, terdapat hubungan negatif antara kecerdasan emosional dengan narcissism pada narapidana remaja di LPKA dan terdapat hubungan negatif antara kecerdasan emosional dengan psychopathy pada narapidana remaja di LPKA.

\section{METODE}

Jenis penelitian ini adalah kuantitatif korelasional.Penelitian korelasional ini mempunyai tujuan untuk menyelidiki variasi variabel antar variabel (Azwar, 2012). Variasi variabel yang diteliti ada 2 yaitu kecerdasan emosional (variabel $\mathrm{X})$ dan dark triad of personality (variabel Y). Khusus untuk variabel dark triad of personality, adalah variabel yang bersifat multidimensional dikarenakan dalam variabel ini terdapat 3 dimensi sekaligus antara lain, machiavellianism, narcissism, dan psychopathy.

Populasi pada penelitian ini adalah narapidana remaja di LPKA Kelas II Tomohon yang berjumlah 16 orang. Adapun pemilihan teknik sampling yang digunakan dalam penelitian ini adalah teknik sampling jenuh yaitu dengan cara mengambil 
semua anggota populasi untuk dijadikan anggota sampel (Sugiyono, 2013), yaitu 16 orang narapidana.

Dalam hal pengumpulan data, peneliti membagikan kuesioner kepada partisipan dengan menggunakan 2 skala pengukuran yang terdiri atas pengukuran kecerdasan emosional dan dark triad of personality. Kedua alat ukur ini menggunakan pernyataan favorable (mendukung) dan unfavorable (tidak mendukung). Selanjutnya untuk pemilihan jawaban dari kedua 'alat ukur ini peneliti menggunakan model Likert yakni dengan pilihan sangat sesuai (SS), sesuai (S), kadang-kadang (KK), tidak sesuai (TS), dan sangat tidak sesuai (STS). Pernyataan favorable diberi skor 5 hingga 1, sedangkan untuk pernyataan unfavorable diberi skor sebaliknya. Alat ukur yang dipakai dalam penelitian ini keduanya diterjemahkan dari bahasa Inggris ke dalam bahasa Indonesia menyesuaikan dengan tempat penelitian yang dilakukan. Proses penerjemahan alat ukur tersebut dilakukan dengan bimbingan dari dosen pembimbing.

Alat ukur kecerdasan emosional menggunakan Schutte Self-report Emotional Intelligence (SSEI), yang dikembangkan oleh Cooper, Dornheim, Golden, Hall, Haggerty, Malouff dan Schutte (1998) dari teori kecerdasan emosional Mayer dan Salovey (1990) yang terdiri dari 33 item dengan 4 aspek pengukuran di dalamnya yaitu, mengenali emosi, memahami emosi, merasakan emosi, dan menggunakan emosi.

Perhitungan uji daya diskriminasi item SSEI dilakukan 1 kali putaran menggunakan SPSS 24 windows version dengan standar corrected itemtotal correlation $\geq 0,2$ yang merupakan standar perhitungan paling rendah (Azwar, 2012). Hasil yang diperoleh dari pengujian tersebut menyisakan 15 dari 33 item yang ada pada skala SSEI dengan tingkat reliabilitas mencapai 0,78 dan tergolong ke dalam standar yang reliabel.

Kemudian perihal alat ukur untuk dark triad of personality, peneliti menggunakan Short Dark Triad (SD3) dari Jones dan Paulhus (2014) yang terdiri dari 3 aspek pengukuran machiavellianism, narcissism, dan psychopathy dengan masing- masing dimensi terdapat 9 item, sehingga jumlah item secara keseluruhan adalah 27. Pengujian daya diskriminasi item serta reliabilitas alat ukur ini menggunakan bantuan SPSS 24 windows version dengan corrected item-total correlation $\geq 0,2$ yang merupakan standar perhitungan paling rendah (Azwar, 2012). Perhitungan pada skala ini dilakukan secara satu per satu dimulai dari aspek pengukuran machiavellianism, narcissism, dan diakhiri dengan psychopathy.

Untuk dimensi machiavellianism sendiri, peneliti memperoleh hasil bahwa dari 9 item yang ada pada machiavellianism, 4 item diantaranya gugur pada pengujian yang dilakukan 1 kali putaran ini dengan tingkatan reliabilitas adalah 0,72 , angka ini tergolong ke dalam standar yang reliabel.

Untuk dimensi narcissism, peneliti melakukan pengujian sebanyak 1 kali putaran dan diperoleh hasil 3 item tersisa dari 9 item yang ada pada aspek narcissism. Sedangkan untuk tingkatan reliabilitas aspek narcissism ini mencapai 0,70 yang berarti masuk ke dalam standar reliabel.

Pengukuran terakhir dilakukan terhadap dimensi psychopathy, yang dalam proses pengujiannya diperoleh hasil akhir 6 dari 9 item tersisa dengan 2 kali putaran uji. Reliabilitas aspek pengukuran ini sebesar 0,80 yang tergolong ke dalam standar reliabel.

Dalam pengujian hipotesis, peneliti menggunakan teknik pengujian korelasional non parametric Spearman Rho yang merupakan uji statistik untuk mengetahui hubungan antara 2 (dua) variabel dengan skala ordinal.

\section{HASIL}

Seluruh narapidana pada penelitian ini adalah laki-laki dengan kisaran usia 16-17 tahun, yang secara kategori hukum tergolong ke dalam narapidana anak dengan lama masa rehabilitasi antara 3 bulan hingga 10 tahun menyesuaikan dengan pelanggaran hukum yang dilakukan narapidana. Kemudian, untuk jenjang pendidikan terakhir dan tahun masuk penjara dapat dilihat di Tabel 1. 
Tabel 1. Data demografis responden penelitian

\begin{tabular}{lll}
\hline \multicolumn{1}{c}{ Variabel } & \multicolumn{1}{c}{ Deskripsi } & Jumlah \\
\hline Pendidikan & TK & 1 \\
& SD & 8 \\
& SMP/sederajat & 7 \\
Tahun masih LPKA & SMA/sederajat & - \\
& 2018 & 1 \\
& 2019 & 2 \\
& 2020 & 13 \\
\hline
\end{tabular}

\subsection{Analisis Deskriptif}

Pengujian statistik deskriptif dilakukan untuk melihat gambaran dari perhitungan data skala Schutte Self-report Emotional Intelligence (SSEI) dan Short Dark Triad (SD3). Uji ini akan melihat hasil perhitungan rata-rata, minimal, maksimal, standar deviasi serta kategorisasi pengukuran dari kedua skala.

Mengacu pada tabel 2, jumlah skor minimum atau yang paling rendah dari kecerdasan emosional adalah 15 dan skor maksimumnya atau paling tinggi yaitu 75 . Skor rata-rata yang diperoleh dari skala ini adalah 52,75 dengan standar deviasi 7,88. Selanjutnya untuk variabel dark triad of personality, dimensi pertama ialah machiavellianism yang menunjukkan skor paling rendah 5 dan paling tinggi 25 disertai dengan skor rata-rata 14,37 dan 3,87 untuk standar deviasi. Dimensi kedua yaitu narcissism mempunyai skor minimum 3 dan skor maksimum 15 , dengan skor rata-rata 8,68 disertai dengan standar deviasi 2,57. Dimensi ketiga adalah psychopathy dengan skor minimum 6 dan skor maksimum 30 dengan perolehan skor rata-rata 14,06 dengan standar deviasi 4,32.

Tabel 2. Hasil uji statistik deskriptif dari kecerdasan emosional dan dark triad of personality

\begin{tabular}{lccccc}
\hline & N & Minimum & Maksimum & Rata-rata & SD \\
\hline Kecerdasan Emosional & 16 & 15 & 75 & 52,75 & 7,88 \\
Machiavellianism & 16 & 5 & 25 & 14,37 & 3,87 \\
Narcissism & 16 & 3 & 15 & 8,68 & 2,57 \\
Psychopathy & 16 & 6 & 30 & 14,06 & 4,32 \\
\hline
\end{tabular}

Kategorisasi kecerdasan emosional dibuat berdasarkan hasil minimum dan maksimum yang didapatkan melalui perhitungan 15 (item lolos seleksi) x 1 (nilai terendah dari skala likert) $=15$ (Minimum) dan 15 (item lolos seleksi) x 5 (nilai tertinggi dari skala likert $)=75$ (Maksimum) . Dari tabel 4, dapat terlihat bahwa narapidana dengan kecerdasan emosional tinggi berjumlah 5 orang dengan persentase $31 \%$. Untuk kategori sedang ada 11 narapidana dengan persentase 69\%, dan tidak ditemukan narapidana yang masuk dalam kategorisasi kecerdasan emosional rendah. Dengen demikian, narapidana di LPKA Kelas II
Tomohon paling banyak memiliki kecerdasan emosional dengan kategorisasi sedang, yakni sebanyak $69 \%$.

Kategorisasi machiavellianism dibuat berdasarkan hasil minimum dan maksimum yang didapatkan melalui perhitungan 5 (item lolos seleksi) x 1 (nilai terendah dari skala likert) $=5$ (Minimum) dan 5 (item lolos seleksi) x 5 (nilai tertinggi dari skala likert) $=25$ (Maksimum). Mengacu pada tabel 5, diketahui terdapat 1 narapidana yang berada dalam kategorisasi machiavellianism tinggi dengan persentase $6 \%$. Untuk kategorisasi sedang terdapat 11 narapidana 
dengan persentase $69 \%$, sedangkan untuk kategorisasi machiavellianism rendah sebanyak 4 orang dengan persentase 25\%. Dari uraian tersebut, dapat terlihat bahwa sebagaian besar narapidana di LPKA Kelas II Tomohon memiliki tingkatan machiavellianism pada kategori sedang yakni sebanyak $69 \%$ dari total keseluruhan narapidana.

Tabel 2. Kategorisasi pengukuran berbagai variabel penelitian

\begin{tabular}{lcccccc}
\hline & Interval & Kategorisasi & Rata-rata & SD & N & Persentase \\
\hline Kecerdasan & $56 \geq \mathrm{x} \leq 75$ & Tinggi & 52,75 & 7,88 & 5 & $31 \%$ \\
Emosional & $36 \geq \mathrm{x} \leq 55$ & Sedang & & & 11 & $69 \%$ \\
& $15 \geq \mathrm{x} \leq 35$ & Rendah & & & 0 & $0 \%$ \\
Machiavellianism & $56 \geq \mathrm{x} \leq 75$ & Tinggi & 52,75 & 7,88 & 5 & $31 \%$ \\
& $36 \geq \mathrm{x} \leq 55$ & Sedang & & & 11 & $69 \%$ \\
& $15 \geq \mathrm{x} \leq 35$ & Rendah & & & 0 & $0 \%$ \\
Narcissism & $12 \geq \mathrm{x} \leq 15$ & Tinggi & 8,68 & 2,57 & 2 & $12 \%$ \\
& $8 \geq \mathrm{x} \leq 11$ & Sedang & & & 10 & $63 \%$ \\
& $3 \geq \mathrm{x} \leq 7$ & Rendah & & & 4 & $25 \%$ \\
& $23 \geq \mathrm{x} \leq 30$ & Tinggi & 14,06 & 4,32 & 0 & $0 \%$ \\
& $15 \geq \mathrm{x} \leq 22$ & Sedang & & & 9 & $56 \%$ \\
& $6 \geq \mathrm{x} \leq 14$ & Rendah & & & 7 & $44 \%$ \\
\hline
\end{tabular}

Kategorisasi narcissism dibuat berdasarkan hasil minimum dan maksimum yang didapatkan melalui perhitungan 3 (item lolos seleksi) x 1 (nilai terendah dari skala likert) $=3$ (Minimum) dan 3 (item lolos seleksi) x 5 (nilai tertinggi dari skala likert) $=15$ (Maksimum). Dalam pengukuran kategorisasi pada dimensi narcissism, 2 narapidana tergolong dalam kategorisasi yang tinggi dengan persentase $12 \%$. Selanjutnya untuk kategorisasi sedang berjumlah 10 narapidana dengan persentase $63 \%$, dan untuk narapidana dengan kategorisasi rendah ada 4 orang dengan persentase $25 \%$. Artinya, melihat dari tabel di atas narapidana dengan kategorisasi narcissism sedang tergolong yang paling banyak.

Kategorisasi narcissism dibuat berdasarkan hasil minimum dan maksimum yang didapatkan melalui perhitungan 6 (item lolos seleksi) x 1 (nilai terendah dari skala likert) $=6$ (Minimum) dan 6 (item lolos seleksi) x 5 (nilai tertinggi dari skala likert) $=30$ (Maksimum). Untuk pengukuran dimensi psychopathy pada narapidana di LPKA Kelas II Tomohon, terlihat bahwa tidak ada narapidana yang masuk ke dalam kategorisasi psychopathy tinggi. Dari tabel 7, dapat diketahui bahwa 9 narapidana masuk dalam kategorisasi sedang dengan persentase $56 \%$ dan 7 narapidana dikategorisasikan rendah dalam psychopathy dengan persentase $44 \%$. Ini berarti, sebagaian besar narapidana masuk dalam kategorisasi sedang dibuktikan dengan persentase yang mencapai $56 \%$.

\subsection{Uji Asumsi}

Pengujian normalitas pada variabel kecerdasan emosional memiliki nilai signifikansi 0,287 (p> 0,05 ), yang berarti variabel tersebut berdistribusi secara normal. Sedangkan pengujian normalitas pada variabel dark triad of personality yang dibagi ke dalam 3 pengujian dimensi yakni machiavellianism, narcissism dan psychopathy, secara berturut-turut mendapati nilai signifikansi $0,474,0,572$ dan 0,967 menandakan variabel tersebut berdistribusi secara normal $(\mathrm{p}>0,05)$.

Adapun hasilnya menunjukkan bahwa terdapat hubungan yang linear antara variabel kecerdasan emosional dan dimensi machiavellianism dari dark triad of personality dengan deviaton from linearity sebesar $\mathrm{F}$ hitung 
2,456 disertai nilai signifikansi 0,200 $(\mathrm{p}>0,05)$. Hubungan linear juga terjadi pada variabel kecerdasan emosional dan dimensi narcissism dari dark triad of personality yang menunjukkan deviation from linearity sebesar F hitung 1,866 disertai nilai signifikansi $0,287 \quad(\mathrm{p}>0,05)$. Kemudian, untuk variabel kecerdasan emosional dengan dimensi psychopathy dari dark triad of personality juga memperlihatkan hubungan yang linear dengan deviation from linearity sebesar $\mathrm{F}$ hitung 0,518 disertai nilai signifikansi 0,818 $(\mathrm{p}>0,05)$.

\subsection{Uji Korelasi}

Hasil uji korelasi kecerdasan emosional dengan dimensi machiavellianism menunjukkan hasil bahwa tidak ada hubungan negatif yang signifikan antara keduanya dibuktikan melalui koefisien korelasi keduanya adalah -0,188 dengan nilai signifikansi $0,243(\mathrm{p}>0,05)$.

Tabel 8. Hasil korelasi antara kecerdasan emosional dan dimensi dark triad of personality

\begin{tabular}{lcccccc}
\hline & Mean & SD & $\mathbf{1}$ & $\mathbf{2}$ & $\mathbf{3}$ & $\mathbf{4}$ \\
\hline 1. Kecerdasan Emosional & 52,75 & 7,88 & 1 & & & \\
2. Machiavellianism & 14,37 & 3,87 & $-0,188$ & 1 & & \\
& & & $(0,243)$ & & & \\
3. Narcissism & 8,68 & 2,57 & $-0,096$ & $-0,101$ & 1 & \\
4. Psychopathy & & & $(0,362)$ & $(0,709)$ & & \\
& 14,06 & 4,32 & $-0,264$ & 0,516 & $-0,191$ & 1 \\
\hline
\end{tabular}

Pengujian korelasi antara kecerdasan emosional dan dimensi narcissism mendapati hasil koefisien korelasi -0,096 dengan nilai signifikansi 0,362 ( $>0,05)$, yang mengindikasikan bahwa tidak ada hubungan negatif yang signifikan antara keduanya. Selanjutnya, pengujian antara kecerdasan emosional dan dimensi psychopathy mendapati hasil koefisien korelasi sebesar -0,264 dengan nilai signifikansi 0,162 ( $p>0,05)$ yang berarti tidak ada hubungan negatif yang signifikan antar keduanya.

Mengacu pada hasil pengujian antar kecerdasan emosional dengan masing-masing dimensi dark triad of personality, dapat diartikan bahwa kecerdasan emosional tidak mempunyai hubungan dengan penurunan ataupun peningkatan dari machiavellianism, narcissism, dan psychopathy.

\section{DISKUSI}

Dengan menitikberatkan pada hasil analisis data dari penelitian mengenai hubungan kecerdasan emosional dan dark triad of personality narapidana di LPKA Kelas II Tomohon, menunjukkan hasil bahwa secara menyeluruh tidak ada hubungan negatif yang signifikan antara kecerdasan emosional dengan 3 dimensi dari dark triad of personality, yakni machiavellianism, narcissism dan psychopathy. Jadi, ketika peningkatan maupun penurunan kecerdasan emosional terjadi, maka itu tidak ada kaitannya dengan dark triad of personality. Begitu pula sebaliknya, jika dark triad of personality mengalami peningkatan dan atau penurunan maka hal tersebut tidak ada kaitannya dengan kecerdasan emosional. Pada akhirnya peneliti menyimpulkan bahwa hipotesis dalam penelitian ini ditolak karena tidak ditemukannya hubungan negatif yang signifikan terhadap kecerdasan emosional dan masing-masing dimensi dari dark triad of personality pada narapidana LPKA Kelas II Tomohon.

Hasil analisis data mengenai hubungan antara kecerdasan emosional dengan machiavellianism memperlihatkan bahwa tidak ada hubungan negatif yang signifikan antar keduanya, dengan perolehan koefisien korelasi -0,188 dan nilai signifikansi 0,243 ( $\mathrm{p}>0,05$ ) (lihat tabel 10). Bereczkei dan Szijjarto (2014) menyatakan bahwa munculnya sifat machiavellianism bukan berasal akibat dari 
kecerdasan emosional yang terganggu tetapi dari seberapa sering interaksi individu dengan orang lain terjadi dan seberapa niat individu tersebut berpartisipasi dengan orang-orang di sekitarnya. Kurangnya moralitas, sinis, hingga penuh manipulatif yang menjadi ciri dari orang dengan machiavellianism sama sekali tidak berkaitan dengan kecerdasan emosional yang tinggi ataupun rendah. Maka dari itu dapat digaris bawahi bahwa keseluruhan sifat machiavellianism yang kemungkinan dimunculkan narapidana tidak dapat dikatakan sebagai hasil dari peningkatan maupun penurunan kecerdasan emosional narapidana.

Kemudian mengenai hubungan kecerdasan emosional dan dimensi narcissism pada narapidana diperoleh skor koefisien korelasi -0,096 dengan signifikansi mencapai 0,362 ( $p>0,05)$. Ini mengindikasikan bahwa tidak ada hubungan negatif yang signifikan antar keduanya. Dengan kata lain, ketika kecerdasan emosional pada narapidana rendah ataupun tinggi, itu tidak ada kaitannya dengan peningkatan atau penurunan dari dimensi narcissism. Czarna, Dufner, Leifed, Salovey dan Smieja (2016) dalam penelitiannya menemukan bahwa antara kecerdasan emosional dan narcissism tidak memiliki hubungan satu dengan lainnya. Hal ini memperkuat temuan dari Ames dan Kammath (2004) yang dalam 2 studi penelitiannya tidak ditemukan sama sekali bukti adanya hubungan antara narcissism dengan proses pengenalan interpersonal. Superioritas, merasa berhak, memegahkan diri sendiri hingga dominasi yang seharusnya menjadi ciri khas dari individu narcissism tidak ada kaitannya dengan terganggunya kecerdasan emosional dari individu. Back, Denissen, Dufner, Gerlach, Kufner, dan Rauthmann (2014) mengemukakan bahwa narcissism adalah multi konstuksi faktorial dengan aspek adaptif yang banyak, maka dari itu ada faktor lain selain kecerdasan emosional yang memiliki peranan penting dalam hubungan antar keduanya. Dengan demikian walaupun narapidana memiliki sifat-sifat yang mengarah pada narcissism dengan kecenderungan tinggi maupun rendah, hal tersebut tidak ada hubungannya dengan kecerdasan emosional.

Temuan-temuan tidak adanya hubungan negatif yang signifikan juga didapati pada hubungan antara kecerdasan emosional dan dimensi psychopathy. Nilai koefisien korelasi keduanya menyentuh angka $-0,264$ dengan skor signifikansi mencapai 0,162 ( $>00,05)$ (lihat tabel 12). Temuan ini dapat dikatakan bahwa ketika adanya peningkatan ataupun penurunan kecerdasan emosional, itu tidak ada hubungannya dengan dimensi psychopathy pada narapidana. Secara teori individu dengan psychopathy cenderung akan dikenal sebagai orang defisit empati terhadap orang lain, namun hal ini jelas dibantah oleh temuan penelitian Ermer, Khan, Kiehl dan Salovey (2012) yang dilakukan pada narapidana di penjara South West Advanced Neuroimaging, dengan hasil menunjukkan bahwa pengalaman kecerdasan emosional individu sama sekali tidak terkait dengan sifat psychopathy. Artinya, ketika individu memiliki sifat psychopathy yang tinggi ataupun rendah, itu tidak ada hubungannya dengan kecerdasan emosional. Locke (2005), menjelaskan bahwa masalah kecerdasan emosional tergantung pada kebiasaan, integritas hingga motivasi individu. Sama halnya terhadap individu psychopathy, yang pada faktanya bahwa dengan mereka memberikan jawaban 'tidak sesuai' ataupun 'sesuai' pada kuesioner penelitian kecerdasan emosional, tidak memberikan arti bahwa individu tersebut kekurangan bentuk kecerdasan emosional. Oleh karena itu, antara keduanya tidak memiliki keterkaitan satu dengan lainnya.

Melihat hasil penelitian yang menunjukkan tidak ada hubungan antara kecerdasan emosional dan masing-masing dimensi dark triad of personality, maka peneliti menduga ada faktorfaktor lain yang dapat berhubungan dengan 3 dimensi tersebut selain kecerdasan emosional yang memang dalam proses analisis data tidak ditemukan adanya keterkaitan. Faktor-faktor tersebut yang kemungkinan besar memiliki hubungan dengan masing-masing dimensi dark triad of personality 
antara lain, jenis kelamin seperti yang ditemukan Jonason dan Davis (2018). Pria cenderung akan lebih memiliki sifat psychopaty dan wanita akan cenderung mengarah pada machiavellianism sedangkan untuk narsisme mengarah pada sifat maskulinitas. Faktor selanjutnya ialah kemampuan kognitif seperti temuan Paulhus dan Williams (2002), yang menyimpulkan bahwa orang dengan dimensi machiavellianism dan psychopathy akan defisit dalam kesadaran dan akan berasosiasi tinggi terhadap kemampuan kognitif, sedangkan untuk narcissism cenderung terlihat asosiasi positif yang rendah pada kemampuan kognitif. Kemudian, ada faktor religiositas yang kemungkinan dapat berhubungan dengan dark triad of personality seperti penemuan dari Lowicki dan Zajenkowski (2017), yang mendapati bahwa orang dengan skor psychopathy dan machiavellianism yang tinggi memiliki kekurangan untuk mengembangkan keyakinan beragama, sedangkan untuk narcissism ditemukan skor tinggi signifikan yang mengarah pada orientasi intrinsik dari religiositas. Faktor terakhir yang kemungkinan dapat berhubungan dengan dimensi-dimensi dark triad of personality adalah motivasi kerja yang ditemukan oleh Drucik dan Szulawski (2019). Dalam penelitian tersebut, secara positif machiavellianism, narcissism dan psychopaty dikaitkan dengan motivasi tinggi yang didapatkan dari lingkungan pekerjaan.

Penemuan ini memperlihatkan bahwa tidak ada sumbangsih dari kecerdasan emosional terhadap dark triad of personality pada narapidana di LPKA. Dari hasil kategorisasi data yang dilakukan, sekitar $31 \%$ narapidana mempunyai kecerdasan emosional tinggi, 69\% diantaranya memiliki kecerdasan emosional sedang dan tidak ditemukannya narapidana dengan tingkatan kecerdasan emosional yang rendah. Untuk dimensi machiavellianism, narapidana dengan kategorisasi tinggi hanya ada 6\%, untuk narapidana dengan kategorisasi sedang ada sekitar 69\%, dan 25\% sisanya masuk ke dalam kategorisasi rendah (lihat tabel 5). Sedangkan untuk dimensi narcissism, hanya $12 \%$ narapidana yang memiliki tingkat narcissism tinggi, $63 \%$ berada pada tahapan sedang, dan 25\% lainnya memiliki tingkatan machiavellianism rendah. Kemudian, untuk dimensi psychopathy tidak ditemukannya narapidana yang masuk dalam kategorisasi tinggi, yang ada hanyalah 56\% narapidana tergolong ke dalam psychopathy sedang dan 44\% lainnya berada pada tingkatan yang rendah. Dengan demikian, peneliti menyimpulkan bahwa kategorisasi tingkatan kecerdasan emosional serta tingkatan dimensi-dimensi dark triad of personaltiy narapidana secara keseluruhan berada pada tingkatan sedang.

Tidak dapat dipungkiri, bahwa dalam studi ini terdapat keterbatasan-keterbatasan yang bisa jadi memengaruhi proses penelitian secara langsung maupun tidak langsung. Keterbatasan pertama ialah, secara kuantitas sampel tergolong sedikit, sehingga kemungkinan berdampak pada proses analisis data yang tidak maksimal. Kedua, peneliti tidak membuat karakteristik kasus/ pelanggaran pidana dari narapidana yang menjadi sampel. Peneliti menduga bahwa kasus/ pelanggaran yang berbeda, akan memunculkan kecerdasan emosional yang berbeda pula. Ketiga, secara menyeluruh sampel yang digunakan peneliti adalah narapidana laki-laki yang memberikan pengertian bahwa hasil hubungan kecerdasan emosional dan dark triad of personality yang dilakukan, hanya berlaku untuk narapidana laki-laki saja, tidak untuk perempuan. Keempat, peneliti tidak melakukan pengambilan data awal terhadap narapidana dikarenakan situasi pandemi covid-19 yang sangat tidak memungkinkan untuk melakukan hal tersebut sehingga peneliti tidak mendapatkan gambaran data awal mengenai alat ukur yang akan digunakan dalam penelitian ini. Kelima, peneliti tidak melakukan survei karakteristik narapidana di LPKA Kelas II Tomohon terlebih dahulu. Peneliti hanya mengambil karakteristik umum dari para narapidana yang ada, sehingga temuan fakta bahwa ada narapidana yang buta huruf cenderung menjadi permasalahan dalam pengisian kuesioner penelitian. Pada akhirnya, kuesioner dari narapidana yang buta huruf tersebut dibantu pengisiannya oleh peneliti dengan cara peneliti 
membacakan item-item kuesioner lalu kemudian narapidana yang menjawabnya.

\section{SIMPULAN}

Berdasarkan dari analisis data penelitian yang dilakukan, maka dapat disimpulkan bahwa tidak ditemukannya hubungan negatif yang signifikan antara kecerdasan emosional dan dimensi dark triad of personality yakni machiavellianism, narcissism dan psychopathy pada narapidana di LPKA Kelas II Tomohon. Dengan hasil tersebut maka hipotesa penelitian ini tidak terbukti.

Adapun saran yang dapat diberikan peneliti bagi LPKA selaku instansi terkait dalam penelitian ini yakni tetap menjalankan program-program rehabilitasi narapidana anak sesuai dengan yang sudah berjalan sebagaimana mestinya di dalam LPKA itu sendiri, seperti program psiko sosial yang meliputi program diskusi kelompok agar terciptanya sebuah interaksi dan komunikasi yang lebih mendalam antar narapidana, program pelatihan soft skill secara berkelompok guna melatih kreativitas dan kerja sama tim, program kepemimpinan sebagai sarana pelatihan sikap menjadi pemimpin hingga konseling rutin untuk narapidana.

Saran untuk pihak yang akan mengembangkan penelitian ini lebih lanjut agar dapat memperhatikan kembali kuantitas sampel hingga karakteristik sampel (jenis pelanggaran, jenis kelamin) yang akan digunakan pada penelitian selanjutnya. Selain itu, bagi peneliti selanjutnya sekiranya dapat menambahkan variabel lain selain kecerdasan emosional yang kemungkinan dapat mempunyai hubungan dengan dimensi-dimensi dark triad of personality, antara lain jenis kelamin (Jonason \& Davis, 2018), kemampuan kognitif (Paulhus \& Williams, 2002), religiusitas (Lowicki \& Zajenkowski, 2017) dan motivasi kerja (Drucik \& Szulawski, 2019).

\section{DAFTAR PUSTAKA}

Ali, F., Amorim, I. S., \& Chamorro-Premuzic, T. (2009). Empathy deficits and trait emotional intelligence in psychopathy and machiavellianism. Personality and Individual Differences, 47, 758-762.

Almeida, P. R., Almosaed, N. F., Bashatah, F. S., Moghrabi, S. S., Morgan, M. M., \& Wright, J. P. (2016). Malevolent forces: Self-control, the dark triad, and crime. Youth Violence and Juventile Justice, 1-25.

Ames, D. R., \& Kammrath, L. K. (2004). Mindreading and metacognition: narcissism, not actual competence, predicts self-estimated ability. Journal of Nonverbal Behavior, 28(3), 187-209.

Andrianto. (2019). Faktor-faktor penyebab kenakalan remaja Lebak Mulyo kecamatan Kemuning kota Palembang. Jornal PAI Raden Patah, 1(1), 82-104

Ansell, E. B., Cain, N. M., Levy, K. N., Pimentel, C. A., Pincus, A. L., \& Wright, A. G. C. (2009). Initial construction and validation of the pathological narcissism inventory. Psychological Assessment, 21(3), 365-379.

Ashton, M. C., Bogaert, A. F., Pozzebon, J. A., \& Visser, B. A. (2010). Psychopathy, sexual behavior, and esteem: It's different for girls. Personality and Individual Differences, 48, 833-838

Austin, E. J., Black, C., Farrelly, D., \& Moore, H. (2007). Emotional intelligence, machiavellianism and manipulation: Does EI have a dark side?. Personality and Individual Differences, 43, 179-189

Azwar, S. (2012). Penyusunan skala psikologi edisi 2. Yogyakarta: Pustaka Belajar.

Back, M. D., Denissen, J. J. A., Dufner, M., Gerlach, T. M., Kufner, A. C. P., \& Rauthmann, J. F. (2014). Narcissistic admiration and rivalry: Disentangling the bright and dark sides of narcissism. Journal of Personality and Social Psychology, 105(6), 1013-1037.

Bahiyah, S., Dewi, F. I. R., Idulfilastri, R. M., \& Marat, S. (2019). Resilience modeling in Indonesian adolecents: Associated with quality of life and self-esteem. Social Science, 
Education and Humanities Research, 439, 131-138.

Bar-On, R. (1997). The Emotional Quotient Inventory (EQ-i): A test of emotional intelligence. Toronto, Canada: Multi-Health Systems.

Bende, D. S., Berghuis, H., Krueger, R. F., Morey, L. C., Skodol, A. E., \& Verheul, R. (2011). Toward a model for assessing level of personality functioning in dsm-5, part ii: Empirical articulation of a core dimension of personality pathology. Journal of Personality Assessment, 93(4), 347-353.

Bereczkei, T., \& Szijjarto, L. (2014). The machiavellians" "cool syndrome": they experience intensive feelings but have difficulties in expressing their emotions. Curr Psychol, 34, 363-375.

Bereczkei, T., \& Szabo, E. (2017). Different paths to different strategies? Unique associations among facets of the dark triad, empathy, and trait emotional intelligence. Adcanves in Cognitive Psychology, 13(4), 306-313.

Bushman, B. J., Corneille, O., Konrath, S., \& Luminet, O. (2014). The relationship between narcissistic exploitativeness, dispositional empathy, and emotion recognition abilities. Journal of Nonverbal Behavior, 38(1), 129-143.

Cleckley, H. (1976). The mask of sanity. St. Louis, MO: Mosby.

Caruso, D. R., Mayer, J. D., \& Salovey, P. (2002). MSCEIT: Mayer-Salovey-Caruso emotional intelligence test. Toronto, Canada: MultiHealth Systems.

Caruso, D. R., Mayer, J. D., \& Salovey, P. (2004). Emotional Intelligence: Theory, findings, and implications. Psychological Inquiry, 15(3), 197-215.

Cooper, J. T., Dornheim, L., Golden, C. J., Haggerty, D. J., Hall, L. E., Malouff, J. M., \& Schutte, N.(1998). Development and validation of a measure of emotional intelligence. Personality and Individual Differences, 25(2), 167-177.
Czarna A. Z., Dufner, M., Leifeld, P., Salovey, P., \& Smieja, M. (2016). Do narcissism and emotional intelligence win us friend? Modeling dynamics of peer population using inferential network analysis. Personality and Social Psychology Bulletin, 1-12

Davis, M., \& Stone, T. (2003). Synthesis: Psychological understanding and social skills, In B. Repacholi \& V. Slaughter. Hove. Sussex: Psychology Press.

Diananda, A. (2018). Psikologi remaja dan permasalahannya. Journal Istighna, 1(1), 116133.

Dishion, T. J., Dodge, K. A., \& Lansford, J. E. (2006). Deviant peer influences in programs for youth: Problems and solutions. The Guilford Press.

Drucik, M., \& Szulawski, M. (2019). The relationship between the dark triad personality, motivation at work, and burnout among HR recruitment workers. Fronties in Psychology, 10.

Ermer, E. Kahn, R. E., Kiehl, K. A., \& Salovey, P. (2012). Emotional intelligence in incarcerated man with psychopathic traits. Journal of Personality and Social Psychology, 103(1), 194-204.

Febiyanti, A., \& Wijaya, E. (2017). Hubungan antara kecerdasan emosional, perilaku delinkuensi, dan prestasi belajar pada remaja madya di SLTA Jakarta. Jurnal Muara Ilmu Sosial, Humaniora, dan Seni, 1(2), 152-158.

Fehr, B., Samsom, D., \& Paulhus, D. L. (1992). Machiavellianism: Twenty years later. In $C$. D. Spielberger \& J. N. Butcher (Eds.), Advances in personality assessment (Vol. 9, pp. 77-116). Hillsdale, NJ: Erlbaum.

Furnham, A., Richards, S. C., \& Paulhus, D. L. (2013). The dark triad of personality: A 10 year review. Social and Personalit y Compass, 7(3), 199-216

Further, M. R., Rauthmann, J. F., \& Sachse, P. (2011). The self-loving self-leader: An examination of the relationship between self- 
leadership and the dark triad. Social Behavior and Personality An International Journal, 39(3), 369-380

Furtner, M. R., Nagler, U. K. J., Rauthmann, J. F., \& Reiter, K. J. (2014). Is there a "dark intelligence"? Emotional intelligence is used by dark personalities to emotionally manipulate others. Personality and Individual Differences, 1-6.

Gilbert, P., \& Morrison, D. (2001). Social rank, shame and anger in primary and secondary psychopaths. The Journal of Forensic Psychiatry, 12(2). 330-356.

Glass, S. J., Malterer, M. B., \& Newman, J. P. (2008). Psychopathy and trait emotional intelligence. Pers Individ Dif, 44(3). 737-745.

Goleman, D. (1999). Working with emotional intelegence: Kecerdasan emosi untuk mencapai puncak prestasi. Jakarta: PT. Gramedia Pustaka Utama

Goleman, D. (2000).Kecerdasan emosi : Mengapa emotional intelligence lebih tinggi daripada IQ, alih bahasa : T. Hermay. Jakarta: PT. Gramedia Pustaka Utama.

Hare, R. D. (2003). The psychopathy checklistrevised. Toronto: ON.

Hare, R. D. (1970). Psychopathy: Theory research, and implications for society. New York, NY: Wiley.

Hare, R. D., \& Neumann, C. S. (2008). Psychopathy as a clinical and empirical construct. Annual Review of Clinical Psychology, 4, 217-241.

Holman, D., Niven, K., \& Totterdell, P. (2012). How to win friendship and trust by influencing people's fellings: An investigation of interpersonal affect regulation and the quality of relationships. Human Relations, 65(6).

Ikanubun, Y. (2016, 12 January). BNN: Pecandu narkoba di Sulawesi Utara 70 persen pelajar. Retrieved from https://www.liputan6.com/regional/read/2409 669/bnn-pecandu-narkoba-di-sulawesi-utara70-persen-pelajar
Jayani, D. H. (2019, 18 July). Daerah mana yang memiliki tindak kejahatan terbanyak. Retrieved from https://databoks.katadata.co. id/datapublish/2019/07/18/daerah-manayang-memilikitindak-kejahatan-terbanyak

Jonason, P.K., \& Webster, G. D. (2012). A protean approach to social influence: Dark triad personalities and social influence tactics. Personality and Individual Differences, 52, 521-526.

Jonason, P. K., \& Davis, M. D. (2018). A gender role view of the dark traits. Personality Individual Differences, 125, 102-105.

Jones, D. N., \& Paulhus, D. L. (2009). Machiavellianism. In, M. R. Leary and R. H. Hoyle (Eds), Handbook of Individual Differences in Social Behavior. New York: Guildford.

Jones, D. N., \& Paulhus, D. L. (2011). The role of impulsivity in the dark triad of personality. Personality and Individual Differences, 51, 679-682.

Jones, D. N., \& Paulhus, D. L. (2014). Introducing the short dark triad (SD3): A brief measure of dark personality traits. Assessment, 21(1), 2841.

KPAI, T. (2013, 12 September). Undang-Undang (UU) RI no. 11 tahun 2012 tentang sistem peradilan anak. Retrieved from https://www.kpai.go.id/hukum/undangundang-uu-ri-no-11-tahun-2012-tentangsistem-peradilan-anak

Kusnandar, V. B. (2019, 22 July). Sepanjang 2017 terjadi 337 ribu tindak kejahatan di Indonesia. Retrieved from https://databoks.katadata.co. id/datapublish/2019/07/22/sepanjang-2017terjadi-337-ribu-tindak-kejahatan-diindonesia\#: : :text=Tindak\%20kejahatan $\% 20 \mathrm{~d}$ i\%20Indonesia\%20yang,100\%20ribu\%20pen duduk\%20dari\%20sebelumnya.

Locke, E. A. (2005). Why emotional intelligence is an invalid concept. Journal of Organizational Behavior, 26(4), 425-431 
Loeber, R. \& Schmaling, K. B. (1985). Empirical evidence for overt and covert patterns of antisocial conduct problems: A metaanalysis. Journal of Abnormal Child Psychology, 13(2), 337-352.

Lowicki, P., \& Zajenkowski, M. (2017). No empathy for people nor for god: The relationship between the dark triad personality, religiosity, empathy. Personality Individual Differences, 115, 169-173

Mayer,J.D., \& Salovey,P.(1989-1990).Emotional intelligence. Imagination, Cognition and Personality, 9(3), 185-211.

Mayer, J. D., \& Salovey, P. (1997). What is emotional intelligence?. New York: Basic Books

Mufarida, B., Purnama, R. R., Rochim, A., \& Yusuf, Y. (2019, 14 March). Tindak kriminalitas anak sangat memprihatinkan. Retrieved from https://nasional.sindonews.com/berita/138654 2/13/tindak-kriminalitas-anak-sangatmemprihatinkan?showpage $=$ all

Nikolaou, I., Tsaousis, I., \& Valoka, M. (2004). The role of emotional intelligence personality variables on attitudes toward organizational change. Journal of Managerial Psychology, 19(2), 88-110.
Paulhus., D. L., \& Williams, K. M. (2002). The dark triad of personality: Narcissism, machiavellianism, and psychopathy. Journal of Researsh in Personality, 36, 556-563.

Petrides, K. V., Schermer, J. A., Vernon, P. A., \& Veselka, L. (2011). Trait emotional intelligence and the dark triad traits of personality. Twin Research and Human Genetics, 14(1), 35-41.

Shepperd, J. A., \& Socherman, R. E. (1997). On the manipulative behavior of low machiavellians: Feigning incompetence to "sandbag" an opponent. Journal of Personality and Social Psychology, 73, 1448-1459.

Sugiyono. (2013). Metode penelitian kuantitatif, kualitatif dan $r \& d$. Bandung: Alfabeta.

Zuraya, N. (2017, 21 July). ICJR: Jumlah tahanan anak di Indonesia meningkat pesat. Retrieved from https://www republika.co.id/berita/nasional/h ukum/17/07/21/otfugz-icjr-jumlah-tahanananak-di-indonesia-meningkat-pesat

Naskah masuk : 3 Februari 2021

Naskah diterima: 14 April 2021 